\title{
Structure Based Design of Non-Natural Peptidic Macrocyclic Mcl-1 Inhibitors
}

Jeffrey W. Johannes, ${ }^{, \dagger}$ (†) Stephanie Bates, ${ }^{\ddagger}$ Carl Beigie, ${ }^{\dagger, \|}$ Matthew A. Belmonte, ${ }^{\dagger}$ John Breen, ${ }^{\dagger}{ }^{\circ}$ Shenggen Cao, ${ }^{\#}$ Paolo A. Centrella, ${ }^{\%}$ Matthew A. Clark, ${ }^{\%}$ John W. Cuozzo, ${ }^{\%}$ Christoph E. Dumelin, ${ }^{\%, @ ~}$ Andrew D. Ferguson, ${ }^{\dagger}$ Sevan Habeshian, ${ }^{\%}$ David Hargreaves, ${ }^{\dagger}$ Camil Joubran, ${ }^{\dagger, \perp}$ Steven Kazmirski, ${ }^{\dagger}, \diamond$ Anthony D. Keefe, ${ }^{\%}$ Michelle L. Lamb, ${ }^{\dagger}$ Haiye Lan, ${ }^{\#}$ Yunxia Li, ${ }^{\#}$ Hao Ma, ${ }^{\#}$ Scott Mlynarski, ${ }^{\dagger}$ Martin J. Packer, ${ }^{\S}$ Philip B. Rawlins, ${ }^{\ddagger}$ Daniel W. Robbins, ${ }^{\dagger, \mathbb{I}}$ Haidong Shen, ${ }^{\#}$ Eric A. Sigel, ${ }^{\%}$ Holly H. Soutter, ${ }^{\%}$ Nancy Su, ${ }^{\dagger}$ Dawn M. Troast, ${ }^{\%, \wedge}$ Haiyun Wang, ${ }^{\dagger}$ Kate F. Wickson, ${ }^{\ddagger}$ Chengyan Wu, ${ }^{\#}$ Ying Zhang, ${ }^{\%}$ Qiuying Zhao, ${ }^{\#}$ Xiaolan Zheng, ${ }^{\dagger}$ and Alexander W. Hird ${ }^{\dagger}$

${ }^{\dagger}$ AstraZeneca R\&D Boston, 35 Gatehouse Drive, Waltham, Massachusetts 02451, United States

${ }^{\ddagger}$ AstraZeneca R\&D Cambridge Science Park, Unit 310 Darwin Building, Cambridge CB4 0WG, United Kingdom

${ }^{\S}$ AstraZeneca R\&D Alderley Park, Macclesfield, Cheshire SK10 4TG, United Kingdom

${ }^{\%}$ X-Chem Pharmaceuticals, 100 Beaver Street, Waltham, Massachusetts 02453, United States

\# Pharmaron Beijing Co., Ltd. 6 Taihe Road BDA, Beijing 100176 P. R. China

Supporting Information

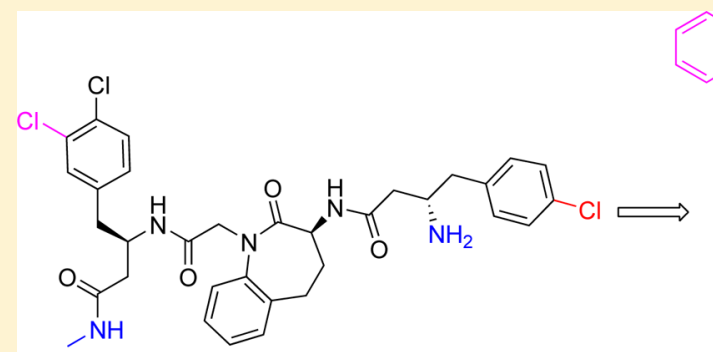

DNA-encoded library hit 2

Mcl-1 FRET IC ${ }_{50}=2 \mu \mathrm{M}$

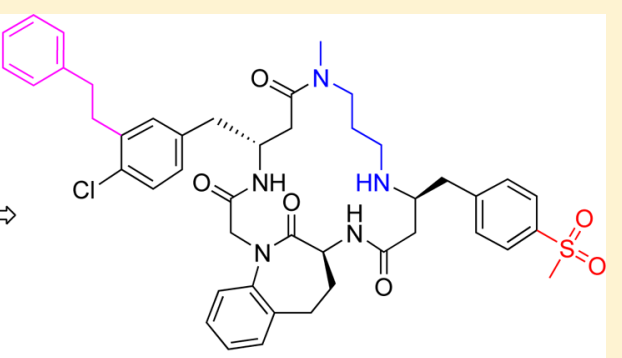

Optimized Compound 26

Mcl-1 FRET IC $50=<3 \mathrm{nM}$

MV4-11 caspase- $3 \mathrm{EC}_{50}=4 \mu \mathrm{M}$

ABSTRACT: Mcl-1 is a pro-apoptotic BH3 protein family member similar to Bcl-2 and Bcl-xL. Overexpression of Mcl-1 is often seen in various tumors and allows cancer cells to evade apoptosis. Here we report the discovery and optimization of a series of non-natural peptide Mcl-1 inhibitors. Screening of DNA-encoded libraries resulted in hit compound 1, a $1.5 \mu \mathrm{M}$ Mcl-1 inhibitor. A subsequent crystal structure demonstrated that compound 1 bound to Mcl-1 in a $\beta$-turn conformation, such that the two ends of the peptide were close together. This proximity allowed for the linking of the two ends of the peptide to form a macrocycle. Macrocyclization resulted in an approximately 10-fold improvement in binding potency. Further exploration of a key hydrophobic interaction with Mcl-1 protein and also with the moiety that engages Arg256 led to additional potency improvements. The use of protein-ligand crystal structures and binding kinetics contributed to the design and understanding of the potency gains. Optimized compound 26 is a $<3 \mathrm{nM} \mathrm{Mcl}-1$ inhibitor, while inhibiting Bcl-2 at only $5 \mu \mathrm{M}$ and Bcl-xL at $>99$ $\mu \mathrm{M}$, and induces cleaved caspase-3 in MV4-11 cells with an $\mathrm{IC}_{50}$ of $3 \mu \mathrm{M}$ after $6 \mathrm{~h}$.

KEYWORDS: Mcl-1, macrocycles, peptides, protein-protein interactions

\footnotetext{
A key hallmark of cancer ${ }^{1}$ is the evolved ability of tumor cells to resist cell death. One mechanism by which this is accomplished is through the up-regulation of antiapoptotic, pro-survival guardian proteins from the Bcl-2 family such as Mcl-1. ${ }^{2}$ In normal cells, Mcl-1 sequesters and protects the cell from the multidomain pro-apoptotic effectors such as BAX. This is necessary because the effectors, if unbound, can form homo-oligomers, which can permeabilize the mitochondrial membrane leading to apoptosis. ${ }^{3}$
}

In normal cells there is a balance between the guardians and effectors maintaining a healthy, live cell. In the presence of stress or external signals, production of initiators (BH3-only proteins such NOXA) occurs. These initiator proteins can bind to the guardians and disrupt the protein-protein interaction

Received: November 15, 2016

Accepted: December 27, 2016

Published: December 27, 2016 
between guardian and effector, releasing the effectors to initiate apoptosis. Cancer cells can overexpress Mcl-1 so that there exists a population of free $\mathrm{Mcl}-1$ that can absorb pro-apoptotic triggers, leading to no net release of effectors and evasion of apoptosis.

Apoptosis can be triggered in Mcl-1 overexpressing cell lines through concomitant expression of the pro-apoptotic inducer protein NOXA. ${ }^{4}$ Conceptually, a cell permeable, small molecule NOXA mimetic could also lead to apoptosis. This small molecule would need to mimic the $\alpha$ helix in the $\mathrm{BH} 3$ domain of NOXA that is able to bind to Mcl-1 and displace bound effector proteins such as BAX or BAK. The approval of the Bcl2 inhibitor venetoclax for treatment of CLL in 2016 has demonstrated the utility of this approach. ${ }^{5}$

Despite the success of venetoclax, the discovery of a small molecule $\mathrm{BH} 3$-only protein mimetic is a significant medicinal chemistry challenge. The interaction between $\mathrm{Mcl}-1$ and effectors/initiators is mediated by the binding of an $\alpha$ helix of the effectors/initiators to a shallow groove on Mcl-1. ${ }^{6}$ This shallow binding groove is predicted to have very low affinity to small molecules due to its large, shallow, solvent exposed surface area. ${ }^{7-10}$ Despite these challenges, extensive efforts to discover Mcl-1 inhibitors have been reported. ${ }^{11}$ A few organizations, such as Amgen, have Mcl-1 inhibitors in clinical trials, ${ }^{12}$ but at this time no Mcl-1 inhibitors have shown clinical activity.

Our efforts to discover a new series of Mcl-1 inhibitors started with an affinity-mediated screen of DNA-encoded libraries ${ }^{13,14}$ with X-Chem Pharmaceuticals in Waltham, MA. We discovered that a library of tripeptide DNA-linked compounds had several structural features that bound to Mcl1. The most commonly bound structural features were assembled into discrete compounds without a DNA tag and tested in an Mcl-1 FRET assay at $0 \%$ serum. ${ }^{15}$ From this initial set, we identified compounds 1 and 2 (Table 1A) as 1.49 and

Table 1. (A) SAR around Initial X-Chem Hit Compound 1 and (B) Subsequent SAR against the Mcl-1 FRET Assay
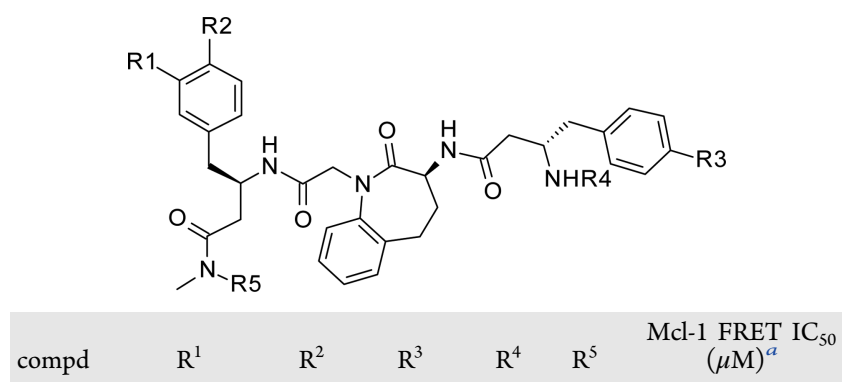

\begin{tabular}{|c|c|c|c|c|c|c|}
\hline \multicolumn{7}{|c|}{ (A) X-Chem Hit SAR } \\
\hline 1 & $\mathrm{Cl}$ & $\mathrm{Cl}$ & $\mathrm{Br}$ & $\mathrm{H}$ & $\mathrm{H}$ & 1.49 \\
\hline 2 & $\mathrm{Cl}$ & $\mathrm{Cl}$ & $\mathrm{Cl}$ & $\mathrm{H}$ & $\mathrm{H}$ & 1.99 \\
\hline 3 & $\mathrm{Cl}$ & $\mathrm{Cl}$ & $\mathrm{H}$ & $\mathrm{H}$ & $\mathrm{H}$ & 19.5 \\
\hline 4 & $\mathrm{H}$ & $\mathrm{Cl}$ & $\mathrm{Cl}$ & $\mathrm{H}$ & $\mathrm{H}$ & 12.5 \\
\hline 5 & $\mathrm{Cl}$ & $\mathrm{H}$ & $\mathrm{Cl}$ & $\mathrm{H}$ & $\mathrm{H}$ & 57.3 \\
\hline \multicolumn{7}{|c|}{ (B) Hybridization Attempts and Acyclic SAR } \\
\hline 6 & $\mathrm{CH}_{2} \mathrm{Ph}$ & $\mathrm{Cl}$ & $\mathrm{Cl}$ & $\mathrm{H}$ & $\mathrm{H}$ & 9.21 \\
\hline 7 & $3 \mathrm{Me}-4 \mathrm{Cl}-\mathrm{Ph}$ & $\mathrm{Cl}$ & $\mathrm{Cl}$ & $\mathrm{H}$ & $\mathrm{H}$ & 1.93 \\
\hline 8 & $\mathrm{CH}_{2} \mathrm{CH}_{2} \mathrm{Ph}$ & $\mathrm{Cl}$ & $\mathrm{Cl}$ & $\mathrm{H}$ & $\mathrm{H}$ & 0.193 \\
\hline 9 & $\mathrm{Cl}$ & $\mathrm{Cl}$ & $\mathrm{Cl}$ & $\mathrm{H}$ & $\mathrm{Me}$ & 2.25 \\
\hline 10 & $\mathrm{Cl}$ & $\mathrm{Cl}$ & $\mathrm{Cl}$ & Et & $\mathrm{H}$ & 2.10 \\
\hline 11 & $\mathrm{CH}_{2} \mathrm{CH}_{2} \mathrm{Ph}$ & $\mathrm{Cl}$ & $\mathrm{SO}_{2} \mathrm{Me}$ & $\mathrm{H}$ & $\mathrm{H}$ & 0.133 \\
\hline
\end{tabular}

${ }^{a}$ See SI Table S2 for number of replicates and SD.
$1.99 \mu \mathrm{M}$ Mcl-1 inhibitors, respectively. Lead hit compound 1 contained a polypeptide architecture featuring a core dihydrobenzazepine $\beta$-turn mimetic linked to a glycine moiety and flanked by two homophenylalanine $\beta$-amino acids of opposite chirality. The terminal methyl carboxamide is the site of the linker to the DNA tag from the DNA-encoded library. In contrast to recently reported highly potent Mcl-1 inhibitors, ${ }^{16-21}$ lead hit $\mathbf{1}$ does not contain an acidic moiety but rather a terminal primary amine. Initial SAR revealed that removal of any halogen atom resulted in a loss of Mcl-1 potency (compounds 3-5), the most important of which is the halogen at $\mathrm{R}^{2}$ in Table $1 \mathrm{~A}$. The compound showed strong preference for the $R, S, S$ stereochemistry as drawn in Table $1 \mathrm{~A}$. All epimers had drastically reduced potency (data not shown).

Due to the lack of an acidic moiety targeting Arg263, we were unable to come up with a convincing binding mode for this series a priori. To facilitate optimization, we crystallized Mcl-1 in the presence of compound 1. The resulting crystals diffracted to give a $2.2 \AA$ resolution structure of compound 1 (cyan) bound to Mcl-1 (purple, Figure 1). The structure

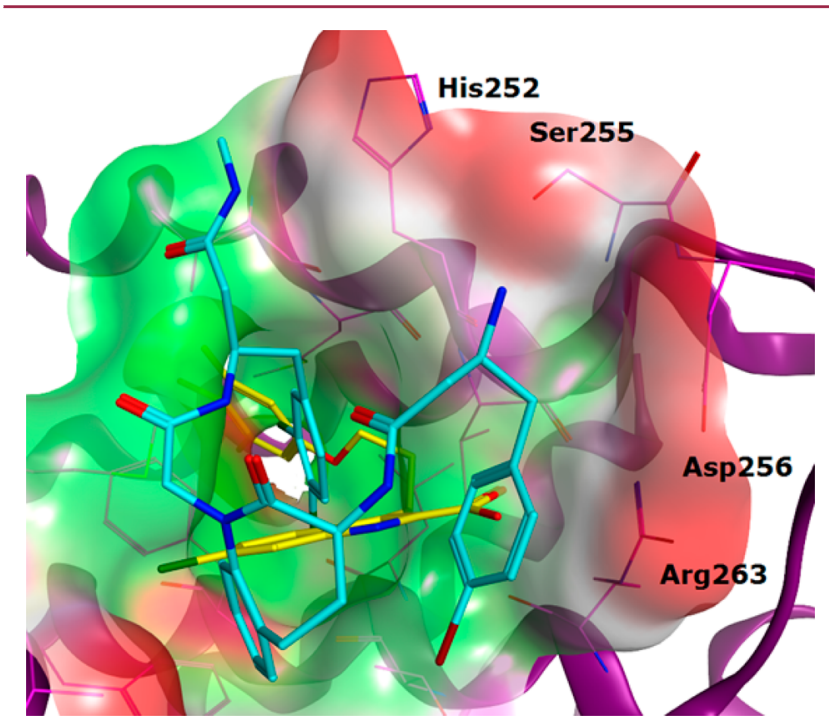

Figure 1. Crystal structure of compound 1 (cyan) bound to Mcl-1 (purple) overlaid with 6-chloro-3-[3-(4-chloro-3,5-dimethylphenoxy)propyl]-1H-indole-2-carboxylic acid (yellow) bound to Mcl-1 (not shown); PDB 5KU9 and 4HW2. Surface colors: red, solvent exposed; green, hydrophobic; magenta, polar.

confirmed that 1 binds to the $\mathrm{BH} 3$ binding groove of $\mathrm{Mcl}-1$ much like the previously reported Mcl-1 inhibitor 6-chloro-3[3-(4-chloro-3,5-dimethyl-phenoxy)propyl]-1H-indole-2-carboxylic acid (yellow compound from $4 \mathrm{HW} 2$ overlaid in Figure 1). ${ }^{14}$ In contrast to the indole acid binding mode, compound 1 does not make a direct H-bond with Arg263. In fact, Arg263 is engaged in a salt bridge with Asp256. The para-bromophenyl moiety packs face to face with the Arg263 through a van der Waals interaction. Overall, the ligand peptide chain adopts a $\beta$ turn configuration with an intramolecular $\mathrm{H}$-bond between the carbonyl group of the bromo-homophenylalanine and the $\mathrm{NH}$ of the glycine. The primary amine forms H-bonds to Ser255 and the backbone carbonyl of His252. Interestingly, the dichlorophenyl moiety is buried in the binding groove, but does not fully exploit the back hydrophobic pocket. Exploitation of this hydrophobic pocket is usually critical for obtaining highly potent Mcl-1 inhibitors. ${ }^{16}$ To this end, we 
Table 2. Macrocyclization Delivers a 10-Fold Improvement in Potency, while Replacement of Chlorine with a Sulfone Enhances Arg263 Interactions, Disrupts the Salt Bridge, and Lowers LiPE

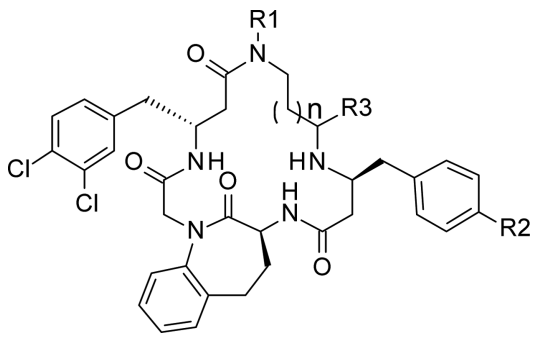

\begin{tabular}{|c|c|c|c|c|c|c|c|c|c|c|}
\hline compd & $\mathrm{R}^{1}$ & $\mathrm{R}^{2}$ & $n$ & $\mathrm{R}^{3}$ & $\begin{array}{l}\text { Mcl-1 FRET 0\% serum } \mathrm{IC}_{50} \\
(\mu \mathrm{M})^{a}\end{array}$ & $\operatorname{cLog} \mathrm{P}^{b}$ & $\mathrm{LiPE}^{c}$ & $\underset{(\mu \mathrm{M})^{a}}{\operatorname{Mcl} 1 \text { SPR }}$ & Mcl-1 SPR $k_{\text {on }}\left(1 / \mathrm{M} \cdot \mathrm{s} \times 10^{5}\right)$ & $\begin{array}{c}\text { Mcl-1 SPR } \\
k_{\text {off }}(1 / s)\end{array}$ \\
\hline 12 & $\mathrm{H}$ & $\mathrm{Cl}$ & 1 & $\mathrm{H}$ & 5.21 & 6.4 & -1.2 & 4.48 & 0.53 & 0.158 \\
\hline 13 & $\mathrm{Me}$ & $\mathrm{Cl}$ & 1 & $\mathrm{H}$ & 0.155 & 7.1 & -0.3 & 0.37 & 7.9 & 0.212 \\
\hline 14 & $\mathrm{Me}$ & $\mathrm{Cl}$ & 2 & $\mathrm{H}$ & 0.122 & 7.6 & -0.7 & 0.29 & 2.9 & 0.082 \\
\hline 15 & $\mathrm{Me}$ & $\mathrm{Cl}$ & 3 & $\mathrm{H}$ & 0.277 & 8.2 & -1.6 & 0.53 & & \\
\hline 16 & $\mathrm{Me}$ & $\mathrm{Cl}$ & 1 & ${ }_{\mathrm{Me}}^{R-}$ & 0.739 & 7.3 & -1.2 & 3.54 & & \\
\hline 17 & $\mathrm{Me}$ & $\mathrm{Cl}$ & 1 & $\stackrel{S-}{\mathrm{Me}}$ & 0.048 & 7.3 & 0.0 & 0.12 & & \\
\hline 18 & $\mathrm{Me}$ & $\mathrm{S}(\mathrm{O}) \mathrm{Me}$ & 1 & $\mathrm{H}$ & 0.742 & 4.8 & 1.4 & 0.77 & & \\
\hline 19 & $\mathrm{Me}$ & $\mathrm{SO}_{2} \mathrm{NH}_{2}$ & 1 & $\mathrm{H}$ & 0.558 & 4.5 & 1.7 & 0.72 & & \\
\hline 20 & $\mathrm{Me}$ & $\mathrm{S}(\mathrm{O})(\mathrm{NH}) \mathrm{Me}$ & 1 & $\mathrm{H}$ & 0.510 & 4.7 & 1.6 & 0.42 & 10.2 & 0.476 \\
\hline 21 & $\mathrm{Me}$ & $\mathrm{SO}_{2} \mathrm{Me}$ & 1 & $\mathrm{H}$ & 0.116 & 4.7 & 2.2 & 0.10 & & \\
\hline
\end{tabular}

${ }^{a}$ See SI Table S2 for replicates and SD. ${ }^{b}$ cLogP v4.3. Pomona College/BioByte, Inc. ${ }^{c}$ pIC50 Mcl-1 FRET 0\% - cLogP (ref 22).

sought to hybridize with the chlorodimethylphenyl example. Based on the overlay in Figure 1, we prioritized the replacement of the meta-chloro group ( $\mathrm{R} 1$ in Table 1B) with hydrophobic, aromatic residues that could mimic the chlorodimethylphenyl group. We synthesized compounds with varied carbon linker lengths such as benzyl compound 6, chloromethylphenyl compound 7, and phenethyl compound 8. The benzyl compound 6 lost potency, while the phenyl compound 7 had only similar potency compared to compound 2 despite its larger size. Gratifyingly, phenethyl compound 8 showed a 10-fold improvement in Mcl-1 binding potency.

From the crystal structure of compound 1, we also noticed that the bound $\beta$-turn conformation positioned the two homophenylalanine groups in close proximity. We hypothesized that additional potency could be achieved if these two ends of the molecule were linked into a macrocycle to preorganize the structure toward the bound conformation. Several points for macrocyclization were considered; however, linking of the terminal primary amine with the methyl carboxamide was prioritized since this linkage (1) created no new stereocenters, (2) only required the formation of carbonheteroatom bonds (more synthetically accessible), and (3) placed the linker in a more solvent exposed region where the likelihood of disruptive clashes was low.

We initially synthesized macrocycle $\mathbf{1 2}$ (Table 2), where R1 was $\mathrm{H}$, but this compound did not show the expected potency improvement relative to $\mathbf{2}$. Based on NOE data obtained for $\mathbf{1 2}$ (see Supporting Information), the amide connected to the linker adopted the trans conformation. Based on the crystal structure of $\mathbf{1}$, it is the cis conformation that is required to link the carboxamide with the primary amine and closely match the bound conformation of $\mathbf{1}$. We postulated that the introduction of a methyl group at R1 of $\mathbf{1 2}$ would force the amide to adopt the cis conformation. Indeed, compound 13 was a $155 \mathrm{nM}$ inhibitor of Mcl-1, showing an over 30-fold improvement in binding potency relative to 12 . NOE data for compound 13 confirmed that the amide conformation had switched to cis (Supporting Information).

Additional acyclic control compounds 9 and 10 (Table 1B) suggest potency gains were not simply a result of additional substitution on 2. Moreover, Mcl-1 SPR binding affinity data for macrocycles 12 and 13 was in line with their FRET $\mathrm{IC}_{50}$ values ( $K_{\mathrm{d}}$ of 4.48 vs $0.37 \mu \mathrm{M}$, respectively). Considering the kinetics, the $k_{\text {off }}$ for both compounds was little changed. Interestingly, the $k_{\text {on }}$ for compound 13 was approximately 10fold faster than $12\left(0.53\right.$ vs $\left.7.91 / \mathrm{M} \cdot \mathrm{s} \times 10^{5}\right)$, suggesting that the potency gained via macrocyclization in $\mathbf{1 3}$ was due to a preorganization of the compound into the bound conformation.

We also made compounds with 4- and 5-atom linkers, but 14 and 15 did not show significant improvement in potency relative to the 3 -atom linked 13 . Simple substitution on the linker generally was not helpful, except for compound 17, a stereochemically pure compound of unknown relative configuration, with a single methyl group alpha to the secondary amine.

We were also cognizant of the fact that this series had high cLogP leading to poor lipophilic efficiencies (LiPE). ${ }^{22}$ For example, macrocycle 13, with a potency of $155 \mathrm{nM}$ and a cLogP of 7.1 has a negative LiPE. To further reduce cLogP while maintaining potency, we sought to replace the chlorine atom at R2 with more hydrophilic groups. Our hypothesis was that lower cLogP groups with $\mathrm{H}$-bond donor and acceptor functionality could engage Arg263. Optimal results came from a subseries of sulfur-based groups such as sulfoxide, sulfonamide, sulfoximine, and sulfone (compounds 18-21 in Table 2). The top compound in this set was compound 21, the methyl sulfone, which maintained Mcl-1 FRET potency of 116 $\mathrm{nM}$ but had improved cLogP leading to a 2-orders of magnitude improvement in LiPE.

Next, Mcl-1 was crystallized in the presence of sulfone $\mathbf{2 1}$ and a monoclonal antibody (see Supporting Information for 
details) to give the crystal structure depicted in Figure 2. This structure shows that $\mathbf{2 1}$ binds in a similar conformation to $\mathbf{1}$.

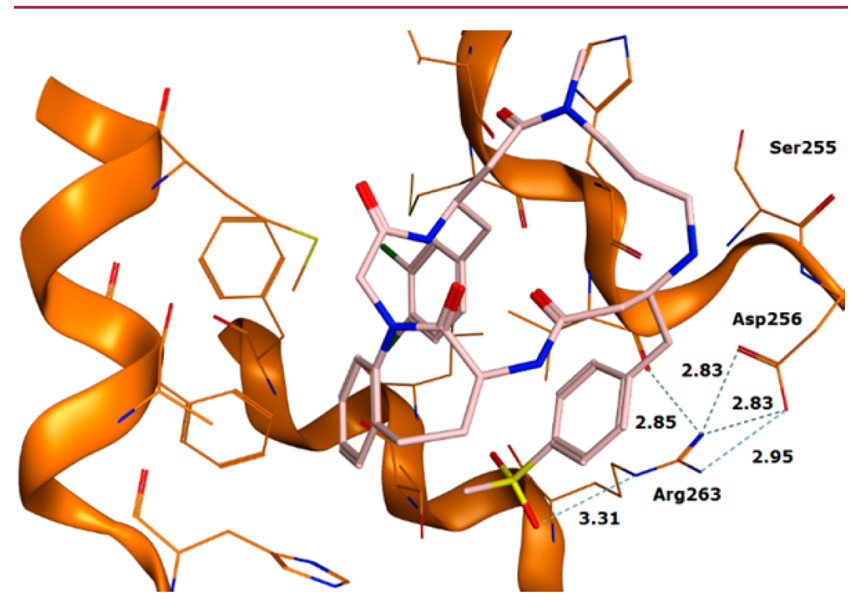

Figure 2. Crystal structure of compound 21 (pink) bound to Mcl-1 (orange); PDB 5MEV (2.94 ̊̊). Distances in $\AA$.

The key difference is the H-bond interaction of the sulfone with Arg263. This interaction causes the Arg263:Asp256 salt bridge to become slightly weakened such that the guanidine plane of Arg263 is twisted relative to the plane of the Asp256 acid, and Ser 255 has pulled away from the ligand. Finally, the $N$-methyl amide adopts the cis conformation in the structure as expected.

With a lower cLogP compound in hand due to the methylsulfone, we could now afford to add some lipophilicity and probe the hydrophobic pocket on the fully elaborated macrocycle. Based on the initial result of the acyclic compound 8, we explored a number of 2-atom linkages to a phenyl group at the meta-position of the disubstituted homophenylalanine moiety. We made and tested the more rigid vinyl linked compound $\mathbf{2 2}$ and alkyne linked compound $\mathbf{2 3}$ (Table 3), but these compounds were not significantly more potent than chloro-substituted compounds 13 or $\mathbf{2 1}$. Highly rigid bicyclic compounds such as the 2-benzofuranyl or 2-naphthyl analogues 24 and 25 also failed to generate any potency improvement relative to $\mathbf{1 3}$ and 21 . Fascinatingly, installing the phenethyl group at R1 on the methyl sulfone macrocycle led to 26 , the most potent analogue made in this series. Compound 26 inhibits the Mcl-1 FRET assay at $<3 \mathrm{nM}$. The SPR measured $K_{\mathrm{d}}$ of $20 \mathrm{nM}$ was in line with this result. Kinetically, compound 26 is unique in this series. With a $k_{\text {on }}$ of $331 / \mathrm{M} \cdot \mathrm{s} \times 10^{5}$ and a $k_{\text {off }}$ of $0.066 \mathrm{1} / \mathrm{s}$, this analogue has both the fastest on rate and the slowest off rate of any compound measured in this series.

The unique potency and kinetic profile of this compound suggested that there was a beneficial, synergistic effect between the large phenethyl group and the para-methyl sulfone moiety. To support this, we synthesized three analogues with a chlorine atom at R2: a vinyl linked phenyl, a 2-benzofuranyl, and a phenethyl compound (27-29, Table 3). Interestingly, all of these compounds were approximately 10 -fold less potent than the corresponding methyl sulfone analogues 22,24 , and 26 , respectively. The switch from the methylsulfonyl to chloro had a drastic negative impact on cLogP and LiPE as well (see SI Table S2). For example, compound 26 has a cLogP of 6.6 and a LiPE of 1.9. The matched chloro analogue 29 has a cLogP of 8.9 and a LiPE of -1.7 , an almost $4 \log$ unit difference.

Comparing the kinetics of chloro vs methylsulfonyl matched pairs 28 vs 24 and 29 vs 26 is quite revealing. For both pairs, the $k_{\text {off }}$ is relatively unchanged ( 0.314 vs 0.336 and 0.073 vs $0.0661 / \mathrm{s}$, respectively). The 10 -fold difference in potency comes almost entirely from a difference in $k_{\text {on }}$ by moving from para-chloro to methylsulfone. Specifically, the $k_{\text {on }}$ for the benzofuranyl compound changes from 1.6 to $9.51 / \mathrm{M} \cdot \mathrm{s} \times 10^{5}$, while the $k_{\text {on }}$ for the phenethyl matched pair changes from 3.7 to $331 / \mathrm{M} \cdot \mathrm{s} \times 10^{5}$.

Increases in on-rate are typically due to a lowering of the barrier between the unbound protein and unbound ligand and the protein-ligand complex. In this specific case, it seems unlikely that switching from chlorine to methyl sulfone at a position so distal from the macrocycle would have an impact on the conformation of the ligand. One possibility is that the interaction of the methylsulfone with Arg263, and subsequent partial disruption of the Arg263:Asp256 salt bridge, has the effect of lowering the barrier between the bound and unbound state of the protein. Another possibility is that the presence of the methylsulfone causes an induced fit between the ligand and protein.

Table 3. Re-Exploration of meta-Chloro Replacements within the Sulfone Macrocycle Subseries

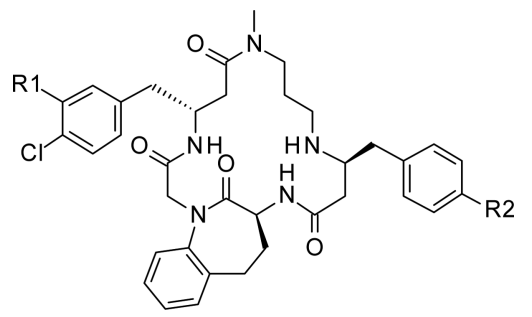

\begin{tabular}{|c|c|c|c|c|c|c|}
\hline compd & $\mathrm{R}^{1}$ & $\mathrm{R}^{2}$ & 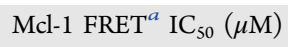 & Mcl-1 SPR $\mathrm{K}_{\mathrm{d}}(\mu \mathrm{M})$ & Mcl-1 SPR $k_{\text {on }}\left(1 / \mathrm{M} \cdot \mathrm{s} \times 10^{5}\right)$ & Mcl-1 SPR $k_{\text {off }}(1 / \mathrm{s})$ \\
\hline 22 & $\mathrm{CH}=\mathrm{CH}-\mathrm{Ph}$ & $\mathrm{SO}_{2} \mathrm{Me}$ & 0.375 & 1.2 & & \\
\hline 23 & $\mathrm{C} \equiv \mathrm{C}-\mathrm{Ph}$ & $\mathrm{SO}_{2} \mathrm{Me}$ & 0.047 & & & \\
\hline 24 & 2-benzofuranyl & $\mathrm{SO}_{2} \mathrm{Me}$ & 0.116 & 0.47 & 9.5 & 0.336 \\
\hline 25 & 2-napthyl & $\mathrm{SO}_{2} \mathrm{Me}$ & 0.112 & 0.29 & 6.6 & 0.213 \\
\hline 26 & $\mathrm{CH}_{2} \mathrm{CH}_{2}-\mathrm{Ph}$ & $\mathrm{SO}_{2} \mathrm{Me}$ & $<0.003$ & 0.02 & 33.0 & 0.066 \\
\hline 27 & $\mathrm{CH}=\mathrm{CH}-\mathrm{Ph}$ & $\mathrm{Cl}$ & 2.23 & $>10$ & & \\
\hline 28 & 2-benzofuranyl & $\mathrm{Cl}$ & 1.05 & 3.6 & 1.6 & 0.314 \\
\hline 29 & $\mathrm{CH}_{2} \mathrm{CH}_{2}-\mathrm{Ph}$ & $\mathrm{Cl}$ & 0.045 & 0.34 & 3.7 & 0.073 \\
\hline
\end{tabular}

${ }^{a} 0 \%$ serum. 
To show that the phenethyl group is buried in the hydrophobic pocket, we produced a crystal structure of chloro-analogue 29 bound to Mcl-1 (Figure 3). From this

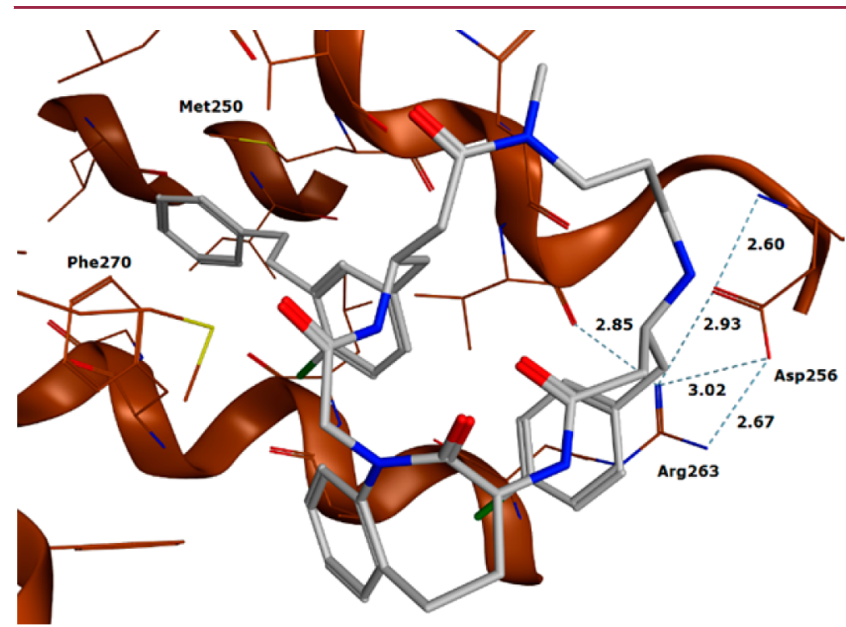

Figure 3. Crystal structure of compound 29 (gray) bound to Mcl-1 (brown); PDB 5MES (2.24 ̊̊). Distances in $\AA$.

structure, it is clear that the phenethyl group is buried in the hydrophobic pocket, and it overlays quite well with the chlorodimethylphenyl from 6-chloro-3-[3-(4-chloro-3,5dimethylphenoxy)propyl]-1H-indole-2-carboxylic acid in 4HW2 (see Supporting Information Figure S3). The flexible ethyl linker is critical to allow the plane of the phenyl group to align correctly in the pocket. The rest of the molecule binds in a similar fashion to the structures in Figures 1 and 2 .

This series was profiled against $\mathrm{Mcl}-1$ paralogs $\mathrm{Bcl}-2$ and $\mathrm{Bcl}-$ $\mathrm{xL}$ (see Supporting Information Table S1). Overall, FRET potencies at $0 \%$ serum ranged from 1 to $40 \mu \mathrm{M}$ for Bcl-2 and between 2 and $>99 \mu \mathrm{M}$ for Bcl-xL. Lead compound 26 was 5.5 $\mu \mathrm{M}$ against $\mathrm{Bcl}-2$ and $>99 \mu \mathrm{M}$ against $\mathrm{Bcl}-\mathrm{xL}$, representing over 1000-fold selectivity for Mcl-1.

Finally, these macrocyclic Mcl-1 inhibitors were tested for their ability to induce apoptosis, as measured by induction of cleaved caspase- 3 after $6 \mathrm{~h}$ compound treatment in MV4-11 cells, a leukemia cell line that is dependent on Mcl-1 for survival (see Supporting Information Table S1). The most potent inhibitor in the Mcl-1 FRET assay, compound 26, was also the most potent compound in the MV4-11 caspase induction assay, with a $6 \mathrm{~h}$ caspase induction $\mathrm{EC}_{50}$ of $3.78 \mu \mathrm{M}$. The approximately 1000-fold shift between the FRET and cell assay occurs due to a combination of (1) changes in assay serum from $0 \%$ to $10 \%,(2)$ low cell permeability of these compounds, and (3) possible competition from endogenous Mcl-1 binding partners.

In conclusion, screening of DNA-encoded libraries resulted in hit compounds $\mathbf{1}$ and $\mathbf{2}$, representing novel non-natural peptidic Mcl-1 inhibitors. Using principles of structure and property based drug design and analysis of the binding kinetics of various analogues, we were able to improve the binding potency of this series around 500-fold without severely compromising the molecular weight or lipophilicity of the series. The observation that the two opposite ends of hit compound 1 sat in close proximity when bound to Mcl-1 led to the successful hypothesis that macrocyclization would improve binding potency through preorganization of the compound toward the bound state. Moreover, we observed a subtle effect between the moiety interacting with Arg263 and the potency of the hydrophobic group occupying the lipophilic back pocket. The insights gained during the optimization of this series may inform the design of increasingly potent inhibitors of this challenging but important target for oncology.

\section{ASSOCIATED CONTENT}

\section{Supporting Information}

The Supporting Information is available free of charge on the ACS Publications website at DOI: 10.1021/acsmedchemlett.6b00464.

FRET data for Bcl-2 and Bcl-xL, cell data, crystal structure renderings, experimental protocols and synthetic procedures (PDF) NMR spectra (PDF)

\section{AUTHOR INFORMATION}

\section{Corresponding Author}

*E-mail: jeffrey.johannes@astrazeneca.com. ORCID

Jeffrey W. Johannes: 0000-0001-7242-6682

Andrew D. Ferguson: 0000-0002-1018-9631

Michelle L. Lamb: 0000-0002-3005-8065

Present Addresses

"Sanofi Genzyme, Office 3216A C-3, One Research Drive, Westborough, Massachusetts 01581, United States.

Foundation Medicine, Inc., 150 Second Street, Cambridge, Massachusetts 02141, United States.

${ }^{\perp}$ Alkermes, Inc., 852 Winter Street, Waltham, Massachusetts 02451, United States.

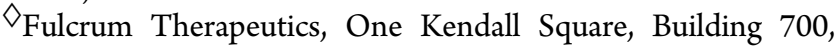
Suite B7102, Cambridge, Massachusetts 02139, United States. IINurix, Inc., 1700 Owens Street, Suite 290, San Francisco, California 94158, United States.

${ }^{\circledR}$ Novartis Institutes for Biomedical Research, Novartis Pharma AG, Basel, Switzerland.

${ }^{\wedge}$ Morphic Therapeutic Inc., 35 Gatehouse Drive, Waltham, Massachusetts 02451, United States.

\section{Author Contributions}

All authors have given approval to the final version of the manuscript.

Notes

The authors declare no competing financial interest.

\section{ABBREVIATIONS}

Bcl-xL, B-cell lymphoma-extra large; Bcl-2, B-cell lymphoma 2; FRET, fluorescence resonance energy transfer; H-bond, hydrogen bond; LiPE, lipophilic efficiency; Mcl-1, Myeloid Cell Leukemia 1; NOE, nuclear Overhauser effect; SPR, surface plasmon resonance

\section{REFERENCES}

(1) Hanahan, D.; Weinberg; Robert, A. Hallmarks of Cancer: The Next Generation. Cell 2011, 144, 646-674.

(2) Taylor, R. C.; Cullen, S. P.; Martin, S. J. Apoptosis: controlled demolition at the cellular level. Nat. Rev. Mol. Cell Biol. 2008, 9, 23141.

(3) Czabotar, P. E.; Lessene, G.; Strasser, A.; Adams, J. M. Control of apoptosis by the BCL-2 protein family: implications for physiology and therapy. Nat. Rev. Mol. Cell Biol. 2014, 15, 49-63.

(4) Oda, E.; Ohki, R.; Murasawa, H.; Nemoto, J.; Shibue, T.; Yamashita, T.; Tokino, T.; Taniguchi, T.; Tanaka, N. Noxa, a BH3- 
only member of the Bcl-2 family and candidate mediator of p53induced apoptosis. Science 2000, 288, 1053-8.

(5) Roberts, A. W.; Davids, M. S.; Pagel, J. M.; Kahl, B. S.; Puvvada, S. D.; Gerecitano, J. F.; Kipps, T. J.; Anderson, M. A.; Brown, J. R.; Gressick, L.; Wong, S.; Dunbar, M.; Zhu, M.; Desai, M. B.; Cerri, E.; Heitner Enschede, S.; Humerickhouse, R. A.; Wierda, W. G.; Seymour, J. F. Targeting $\mathrm{Bcl} 2$ with venetoclax in relapsed chronic lymphocytic leukemia. N. Engl. J. Med. 2016, 374, 311-22.

(6) Czabotar, P. E.; Lee, E. F.; van Delft, M. F.; Day, C. L.; Smith, B. J.; Huang, D. C.; Fairlie, W. D.; Hinds, M. G.; Colman, P. M. Structural insights into the degradation of Mcl-1 induced by $\mathrm{BH} 3$ domains. Proc. Natl. Acad. Sci. U. S. A. 2007, 104, 6217-22.

(7) Arkin, M. R.; Wells, J. A. Small-molecule inhibitors of proteinprotein interactions: progressing towards the dream. Nat. Rev. Drug Discovery 2004, 3, 301-17.

(8) Arkin, M. R.; Tang, Y.; Wells, J. A. Small-molecule inhibitors of protein-protein interactions: progressing toward the reality. Chem. Biol. 2014, 21, 1102-14.

(9) Wells, J. A.; McClendon, C. L. Reaching for high-hanging fruit in drug discovery at protein-protein interfaces. Nature 2007, 450, 10019.

(10) Raj, M.; Bullock, B. N.; Arora, P. S. Plucking the high hanging fruit: a systematic approach for targeting protein-protein interactions. Bioorg. Med. Chem. 2013, 21, 4051-7.

(11) Beekman, A. M.; Howell, L. A. Small-Molecule and Peptide Inhibitors of the Pro-Survival Protein Mcl-1. ChemMedChem 2016, 11, $802-13$.

(12) https://clinicaltrials.gov/ct2/show/NCT02675452 (accessed September 30th, 2016).

(13) Clark, M. A.; Acharya, R. A.; Arico-Muendel, C. C.; Belyanskaya, S. L.; Benjamin, D. R.; Carlson, N. R.; Centrella, P. A.; Chiu, C. H.; Creaser, S. P.; Cuozzo, J. W.; Davie, C. P.; Ding, Y.; Franklin, G. J.; Franzen, K. D.; Gefter, M. L.; Hale, S. P.; Hansen, N. J.; Israel, D. I.; Jiang, J.; Kavarana, M. J.; Kelley, M. S.; Kollmann, C. S.; Li, F.; Lind, K.; Mataruse, S.; Medeiros, P. F.; Messer, J. A.; Myers, P.; O’Keefe, H.; Oliff, M. C.; Rise, C. E.; Satz, A. L.; Skinner, S. R.; Svendsen, J. L.; Tang, L.; van Vloten, K.; Wagner, R. W.; Yao, G.; Zhao, B.; Morgan, B. A. Design, synthesis and selection of DNA-encoded small-molecule libraries. Nat. Chem. Biol. 2009, 5, 647-54.

(14) Litovchick, A.; Dumelin, C. E.; Habeshian, S.; Gikunju, D.; Guié, M.-A.; Centrella, P.; Zhang, Y.; Sigel, E. A.; Cuozzo, J. W.; Keefe, A. D.; Clark, M. A. Encoded Library Synthesis Using Chemical Ligation and the Discovery of sEH Inhibitors from a 334-Million Member Library. Sci. Rep. 2015, 5, 10916.

(15) The FRET assay was run with both $0 \%$ and $2 \%$ serum for all compounds. In general for this series, the fold-shift in $\mathrm{IC}_{50}$ was relatively minor moving from $0 \%$ to $2 \%$ serum. See the Supporting Information Table $\mathrm{S} 1$ for $2 \%$ serum FRET data.

(16) Friberg, A.; Vigil, D.; Zhao, B.; Daniels, R. N.; Burke, J. P.; Garcia-Barrantes, P. M.; Camper, D.; Chauder, B. A.; Lee, T.; Olejniczak, E. T.; Fesik, S. W. Discovery of potent myeloid cell leukemia 1 (Mcl-1) inhibitors using fragment-based methods and structure-based design. J. Med. Chem. 2013, 56, 15-30.

(17) Fang, C.; D'Souza, B.; Thompson, C. F.; Clifton, M. C.; Fairman, J. W.; Fulroth, B.; Leed, A.; McCarren, P.; Wang, L.; Wang, Y.; Feau, C.; Kaushik, V. K.; Palmer, M.; Wei, G.; Golub, T. R.; Hubbard, B. K.; Serrano-Wu, M. H. Single diastereomer of a macrolactam core binds specifically to myeloid cell leukemia 1 (MCL1). ACS Med. Chem. Lett. 2014, 5, 1308-12.

(18) Bruncko, M.; Wang, L.; Sheppard, G. S.; Phillips, D. C.; Tahir, S. K.; Xue, J.; Erickson, S.; Fidanze, S.; Fry, E.; Hasvold, L.; Jenkins, G. J.; Jin, S.; Judge, R. A.; Kovar, P. J.; Madar, D.; Nimmer, P.; Park, C.; Petros, A. M.; Rosenberg, S. H.; Smith, M. L.; Song, X.; Sun, C.; Tao, Z. F.; Wang, X.; Xiao, Y.; Zhang, H.; Tse, C.; Leverson, J. D.; Elmore, S. W.; Souers, A. J. Structure-guided design of a series of MCL-1 inhibitors with high affinity and selectivity. J. Med. Chem. 2015, 58, 2180-94.

(19) Burke, J. P.; Bian, Z.; Shaw, S.; Zhao, B.; Goodwin, C. M.; Belmar, J.; Browning, C. F.; Vigil, D.; Friberg, A.; Camper, D. V.;
Rossanese, O. W.; Lee, T.; Olejniczak, E. T.; Fesik, S. W. Discovery of tricyclic indoles that potently inhibit Mcl-1 using fragment-based methods and structure-based design. J. Med. Chem. 2015, 58, 3794805.

(20) Pelz, N. F.; Bian, Z.; Zhao, B.; Shaw, S.; Tarr, J. C.; Belmar, J.; Gregg, C.; Camper, D. V.; Goodwin, C. M.; Arnold, A. L.; Sensintaffar, J. L.; Friberg, A.; Rossanese, O. W.; Lee, T.; Olejniczak, E. T.; Fesik, S. W. Discovery of 2-indole-acylsulfonamide myeloid cell leukemia 1 (Mcl-1) inhibitors using fragment-based methods. J. Med. Chem. 2016, 59, 2054-66.

(21) Kotschy, A.; Szlavik, Z.; Murray, J.; Davidson, J.; Maragno, A. L.; Le Toumelin-Braizat, G.; Chanrion, M.; Kelly, G. L.; Gong, J.-N.; Moujalled, D. M.; Bruno, A.; Csekei, M.; Paczal, A.; Szabo, Z. B.; Sipos, S.; Radics, G.; Proszenyak, A.; Balint, B.; Ondi, L.; Blasko, G.; Robertson, A.; Surgenor, A.; Dokurno, P.; Chen, I.; Matassova, N.; Smith, J.; Pedder, C.; Graham, C.; Studeny, A.; Lysiak-Auvity, G.; Girard, A.-M.; Gravé, F.; Segal, D.; Riffkin, C. D.; Pomilio, G.; Galbraith, L. C. A.; Aubrey, B. J.; Brennan, M. S.; Herold, M. J.; Chang, C.; Guasconi, G.; Cauquil, N.; Melchiore, F.; Guigal-Stephan, N.; Lockhart, B.; Colland, F.; Hickman, J. A.; Roberts, A. W.; Huang, D. C. S.; Wei, A. H.; Strasser, A.; Lessene, G.; Geneste, O. The MCL1 inhibitor $S 63845$ is tolerable and effective in diverse cancer models. Nature 2016, 538, 477-482.

(22) Leeson, P. D.; Springthorpe, B. The influence of drug-like concepts on decision-making in medicinal chemistry. Nat. Rev. Drug Discovery 2007, 6, 881-90. 